\title{
PENGARUH PEMBERIAN SENAM OTAK TERHADAP MEMORI JANGKA PENDEK PADA MAHASISWA IKOR FIK UNIMED
}

\author{
Oleh \\ Deni Rahman Marpaung ${ }^{1}$, Zulaini ${ }^{2}$, Yosef Alfonsus ${ }^{3}$ \\ ${ }^{1}$ Fakultas Ilmu Keolahragaan Universitas Negeri Medan \\ ${ }^{2}$ Fakultas Ilmu Keolahragaan Universitas Negeri Medan \\ ${ }^{3}$ Fakultas Ilmu Keolahragaan Universitas Negeri Medan \\ Email: rahmanmarpaung@gmail.com
}

\begin{abstract}
Abstrak
Tujuan penelitian ini adalah untuk mengetahui Pengaruh Senam Otak Terhadap Memori Jangka Pendek Pada Mahasiswa Jurusan Ilmu Keolahragaan FIK UNIMED. Penelitian ini menggunakan metode eksperimen. Sampel yang digunakan merupakan mahasiswa IKOR FIK Unimed dengan jumlah 54 orang, dengan rincian yaitu 22 orang mahasiswa IKOR kelas A sebagai kelompok eksperimen (diberikan senam otak selama satu minggu dengan waktu 1 jam sehari) dan 32 orang mahasiswa IKOR kelas B/sebagai kelompok kontrol (tidak diberikan senam otak). Teknik analisis data-dengan metode SPSS versi 17. Hasil analisis statistika diperoleh menunjukkan bahwa ada peningkatan jumlah sampel yang-memiliki memori jangka pendek pada kelompok eksperimen yaitu sebesar $48,28 \%$ (14 orang) sebelum diberikan senam otak mejadi menjadi $77,27 \%$ (17 orang) dengan kategori baik. Penelitian ini sangat bermanfaat bagi mahasiswa untuk meningkatkan memori jangka pendek salah satunya bisa dilakukan dengan latihan senam otak minimal 15-30 menit dalam sehari.
\end{abstract}

Kata Kunci : Senam Otak, Memori Jangka Pendek

\section{A. PENDAhULUAN}

Otak atau encephalon adalah pusat sistem saraf/ CNS (Central Nervous System) pada vertebrata dan banyak invertebrata lainnya. Otak mengatur dan mengkoordinir sebagian besar, gerakan, perilaku, dan fungsi tubuh homeostatis, seperti detak jantung, tekanan darah, ataupun keseimbangan cairan dan suhu tubuh. Otak juga bertanggungjawab atas fungsi, misalnya pada pengenalan, emosi, ingatan, pembelajaran motorik, dan segala bentuk pembelajaran lainnya (As'adi, 2013).

Otak terdiri dari dua belahan, yakni otak kiri dan otak kanan. Otak kiri berfungsi mengatur badan bagian kanan agar bisa berfikir logis, rasional, menganalisis, berbicara, berorientasi pada waktu hal-hal yang rinci, pusat matematika, ataupun kemampuan menulis dan membaca. Beberapa pakar menyebutkan bahwa otak kiri merupakan pusat Intelligence Quotient (IQ). Sementara itu otak kanan mempunyai fungsi perkembangan Emotional Quotient (EQ). Dalam bidang intuitif, seperti merasakan, bermusik, menari, kreatif, melihat keseluruhan, dan ekspresi badan (Yanuarita, 2012). 
Manusia dalam kehidupan sehari-hari tidak terlepas dari proses belajar dan mengingat, yang sangat berkaitan dengan memori. Memori adalah suatu proses penyimpanan dan pengeluaran kembali informasi yang didapat dari proses belajar. Sejalan dengan berjalannya usia memori atau daya ingat akan mengalami penurunan. Penurunan memori (daya ingat) atau dimentia, yang dalam bahasa sehari-hari dikenal dengan istilah pikun, merupakan gejala yang sering dijumpai pada lanjutusia, terutama diatas usia 40 tahun. Akan tetapi bagi yang pelupa pada usia muda, penyebabnya mungkin karena kelelahan otak atau stress, yang mengakibatkan daya ingat tidak cukup kuat. Secara alamiah, penurunan daya ingat umumnya karena beberapa sel otak terutama sel dendate gyrus yang berangsur-angsur mulai mati, juga karena berkurangnya daya elastisitas pembuluh darah. Sel otak yang mulai mati tersebut tidak akan mengalami regenerasi, sehingga hal ini yang menyebabkan seseorang menjadi mudah lupa.

Memori jangka pendek memiliki peranah penting dalam pikiran sadar.Jika secara sadar kita meneoba memecahkan suatu masalah, kita-sering menggunakan memori jangka pendek sebagai ruang kerja mental dan menggunakannya untuk menyimpan bagian-bagian masalah serta informasi yang diambil dari memori jangka panjang yang relevan dengan masalah. Memori jangka pendek selain memiliki dua fungsi penting yaitu menyimpan material yang diperlukan untuk periode waktu yang pendek dan berperan sebagai ruang kerja untuk perhitungan mental, kemungkinan fungsi lain adalah bahwa memori jangka pendek merupakan stasiun perhentian ke memori jangka panjang. Artinya, informasi mungkin berada di memori jangka pendek sementara ia sedang disandikan menjadi memori jangka panjang. Memori jangka panjang akan menyimpan memori untuk bertahun-tahun bahkan kadang seumur hidup.

Memori (daya ingat) dipengaruhi oleh faktor fisiologi, psikologis, dan patologis seperti: usia, jenis makanan, olahraga (latihan fisik), latihan memori berulang-ulang, kemampuan berkonsentrasi, hormonal, jenis kelamin, gen, dan lain-lain.

Organ yang berperan terhadap faktor memori yaitu otak, tepatnya pada lobus temporalis. Untuk meningkatkan memori ini dibutuhkan latihan fisik, aktifitas stimulus intelektual, nutrisi khusus, olahraga teratur, dan istirahat cukup agar berfungsi optimal. Latihan fisik untuk meningkatkan daya ingat, dapat dilakukan dengan olahraga. Salah satu olahraga yang mampu mengoptimalkan fungsi otak adalah dengan senam otak. 
Gerakan yang ada dalam senam otak dapat memperlancar aliran darah dari tubuh ke otak dan sebaliknya sehingga fungsi otak dapat dioptimalkan (Munir, 2003).

Awal mula senam otak ini dulunya memang hanya dilakukan untuk anak-anak yang berkebutuhan khusus atau anak-anak yang mengalami kesulitan di dalam konsentrasi dan belajar, namun akhirnya senam otak ini lebih dikembangkan tanpa membedakan usia, mengingat semua orang ingin mempunyai kesempatan belajar tanpa memandang batas usia. Di dalam Brain Gym (senam otak) mengajarkan gerakangerakan yang mudah diingat dan dilakukan serta dapat membantu banyak orang, muda, atau tua untuk mengoptimalkan kemampuan belajarnya (Dennison, 2008 ).

Senam otak mempunyai prinsip dasar agar otak tetap bugar dan mencegah kepikunan serta mempunyai tujuan utama untuk mempertahankan kesehatan otak dengan melakukan gerakan badan. Latihan senam otak akan dapat membantu menyeimbangkan fungsi otak. Baik itu otak kanan dan otak kiri (dimensi lateralitas), otak belakang/ batang otak dan otak depan/frontal lobes (dimensi pèmfokusan) serta sistem limbis (misbrain) dan otak besar/cerlebral cortex (dimensi pemusatan), dalam senam otak terdapat gerakan-gerakan terkoordinasi yang dapat menstimulasi kerja otak sehingga lebih aktif (Dennison, 2008).

Manfaat yang bisa diperoleh dengan melakukan senam otak, seperti meningkatkan kemampuan kognitif (kewaspadaan, konsentrasi, kecepatan, persepsi, pemecahan masalah dan kreatifitas). Dengan melakukan gerakan senam otak ini, semua untuk memudahkan berkonsentrasi dalam melaksanakan dan mengerjakan tugas maupun berfikir secara tepat akan situasi tertentu, serta kemampuan memecahkan masalah situasi tersebut. Menurut Yanuarita (2012) kemampuan berfikir aplikasi dari individu melalui pengenalan yang lalu.Dengan demikian, bahwa dengan senam otak dapat membantu untuk menyelesaikan pekerjaan dengan baik.

Dalam mengingat informasi berupa materi pelajaran, mahasiswa memiliki strategi belajar masing-masing. Berdasarkan survey yang didapat oleh peneliti dari mahasiswa FIK Unimed Jurusan Ilmu Keolahragaan, bahwa mahasiswa memiliki metode belajar yang biasanya mereka terapkan. Adapun strategi belajar yang peneliti dapatkan yaitu mencatat ulang materi yang mereka pelajari, membuat resume, membaca slide, diskusi dengan teman, menghapal materi, dan sistem kebut semalam yang menjadi favorit mahasiswa. 
Menurut pengalaman peneliti, selama kegiatan perkuliahan, mahasiswa yang mencatat termasuk dalam kategori sedikit. Kebanyakan mahasiswa hanya membaca makalah, mendengarkan ceramah ataupun membaca slide presentasi yang disampaikan padahal untuk dapat mengingat suatu informasi secara efektif, tidak cukup hanya dengan membaca dan mendengar saja. Adapun mahasiswa yang mencatat masih menggunakan metode linier yang hanya terpaku pada tulisan yang panjang dan belum sistematis. Mahasiswa hanya menggunakan proses otak bagian kiri ketika belajar. Mahasiswa hanya terpaku pada proses belajar yang menggunakan angka, linearitas, analisis, dan daftar yang semuanya merupakan kerja otak kiri, dari pada irama, kesadaran ruang, imajinasi, kreatifitas yang merupakan kerja otak kanan. Sistem pendidikan modern memang lebih cenderung untuk menggunakan otak kiri seperti hitungan, bahasa, dan ilmu pengetahuan lainnya daripada menggunakan otak kanan seperti keterampilan berpikir secara kreatif (Buzán, 2006).

Mahasiswa akan lebih mudah mengingat/informasi jika mennggunakan kedua belahan otak. Latihan yang mémadukan kedAaybelahan otak, yaitu belahan otak kiri dan belahan otak kanan adalah dengan melakukan latihan senam otak. Manfaat yang bisa diperoleh dengan melakukan senam otak, seperti meningkatkan kemampuan kognitif (kewaspadaan, konsentrasi, kecepatan, persepsi, pemecahan masalah dan kreatifitas). Dengan melakukan gerakan senam otak ini, semua untuk memudahkan berkonsentrasi dalam melaksanakan dan mengerjakan tugas maupun berfikir secara tepat akan situasi tertentu, serta kemampuan memecahkan masalah situasi tersebut.Sehinggadiharapkan dapat memudahkan mahasiswa dalam berkonsentrasi, melaksanakan, dan mengerjakan tugas maupun berfikir secara tepat akan situasi tertentu serta kemampuan memecahkan masalah (Yanuarita 2012).

Berdasarkan data awal hasil tes memori jangka pendek pada mahasiswa Jurusan Ilmu Keolahragaan stambuk 2013 sebanyak 30 orang, didapat kategori rendah sebesar $40 \%$ (12 orang), kategori sedang sebesar 50\% (15 orang), kategori baik sebesar 10\% (3 orang) . Berdasarkan latar belakang inilah peneliti ingin melakukan penelitian tentang pengaruh pemberian senam otak terhadap memori jangka pendek pada mahasiswa Ilmu Keolahragaan FIK Unimed. 


\section{B. METODE PENELITIAN}

Metode yang digunakan dalam penelitian ini adalah metode quasi eksperimen (eksperimen semu), yaitu pemberian perlakuan pada sampel. Lokasi penelitian dilakukan di Fakultas Ilmu Keolahragaan Unimed. Pengambilan data dilakukan selama 2 minggu dengan durasi minimal 15 menit-30 menit sehari.

Populasi dalam penelitian ini merupakan seluruh mahasiswa Ilmu Keolahragaan Stambuk 2014 yang berjumlah 63 orang mahasiswa dengan rincian 29 mahasiswa dari Kelas A dan 34 Mahasiswa dari kelas B.

Sampel penelitian ini adalah dengan menggunakan purposive sampling yaitu pengambilan sampel berdasarkan pada suatu pertimbangan tertentu yang dibuat oleh peneliti sendiri berdasarkan kebutuhan penelitian tanpa menghilangkan ciri dan sifatsifat populasi yang sudah diketahui sebelumnya (Arikunto, 2006). Adapaun kriteria sampel tersebut adalah : 1) Mahasiswa IKOR Stambuk 2014; 2) Bersedia mengikuti program senam otak secara teratur; 3) Telah mengikuti tes awal memori jangka pendek.

- Berdasarkan kriteria sámpel diatas Anaka diperoleh samper sebanyak 54 orang mahasiswa yang dibagi menjadi 2 kelompok. Kelompok A (yang mendapatperlakukan senam otak) sebanyak 22 orang dan kelompok B (kelompok kontrol) sebanyak 32 orang.

Tahapan proses penelitian akan dilakukan dalam tiga tahap yaitu tes memori jangka pendek, pemberian senam otak selama 2 minggu dan tes memori jangka pendek. Pemberian senam otak dilakukan dengan cara melakukan gerakan-gerakan sena otak, latihan-latihan otak kiri dan otak kanan dengan bermain puzzle, membaca cerita fiksi, bermain sudoku, mengisi TTS dan mendengarkan musik klasik.

Alat untuk mengukur memori jangka pendek yang digunakan dalam penelitian ini yaitu alat tulis, stopwatch, dan lembar test IST (Intelligenz Struktur Test), yang diberikan oleh kalangan orang psikologi saja.

Untuk menguji hipotesis dilakukan dengan analisis Paired Samples Test pada metode SPSS (Statistical Product and Service Solutions). Setelah itu, kemudian dilakukan tes uji normal data, dimana data dikatakan normal apabila $p>0,05$. Selanjutnya setelah data normal maka dilanjutkan dengan uji paired samples test yang bertujuan untuk melihat apakah terdapat perbedaan pengaruh senam otak terhadap memori jangka pendek antara kelompok eksperimen dengan kelompok kontrol. 


\section{HASIL DAN PEMBAHASAN}

1. Hasil

Hasil penelitian ini menunjukkan bahwa sampel pada kelompok eksperimen mengalami peningkatan kemampuan memori jangka pendek dengan kategori baik, yaitu dari 14 orang $(48,28 \%)$ naik menjadi 17 orang $(77,27 \%)$. Sedangkan pada kelompok kontrol mengalami penurunan peningkatan kemampuan memori jangka pendek dengan kategori baik, yaitu 23 responden $(67,65 \%)$ turun menjadi 20 responden $(62,50 \%)$.

Hasil penelitian dengan uji statistika Mann Whitney U Test didapatkan $\mathrm{p}_{\text {value }}$ sebesar 0,004. Pengambilan keputusan dilakukan dengan melihat derajat kemaknaan $(\alpha=0,05)$, yaitu apabila $p$ value $\leq 0,05$ maka $H_{O}$ ditolak. Maka dapat disimpulkan bahwa ada pengaruh pemberian senam otak terhadap kemampuan memori jangka pendek pada Mahasiswa IKOR FIK Unimed.

2. Pembahasan

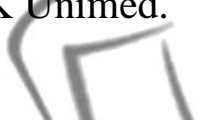

Data mengenai karakteristik responden pada penelitian sat in menyatakan bahwa usia rata-rata responden pada kelompok kontrol dan kelompok eksperimen adalah 19 tahun. Hasil diatas menunjukkan bahwa usia responden adalah kelompok usia yang sama yaitu usia seorang mahasiswa pada perguruan tinggi. Kemampuan memori jangka pendek pada kelompok usia yang sama memiliki persamaan dalam kemampuan memorinya (Mundkur, 2005). Teori yang dikembangkan oleh Chugani (1998) menyatakan bahwa otak memiliki sifat plastisitas yang dapat membuat kemampuan otak dalam memori semakin berkembang ketika otak semakin banyak digunakan. Responden yang merupakan usia mahasiswa perguruan tinggi masih dapat mengalami peningkatan kemampuan memori jangka pendek, sehingga diperlukan stimulasi untuk meningkatkannya.

Adanya responden yang memiliki kemampuan memori jangka pendek baik sebelum diberikan senam otak dapat disebabkan karena tingkat pengetahuan mahasiswa yang tinggi. Responden yang memiliki kemampuan memori jangka pendek yang cukup dan buruk dapat disebabkan karena kurangnya stimulasi yang diberikan, padahal otak dapat menumbuhkan koneksi yang baru dengan adanya stimulasi yang teratur.

Stimulasi yang cukup dapat membuat otak memiliki korteks yang lebih tebal, percabangan dendrit dan spina menjadi lebih banyak sehingga sel otak semakin berkembang (Harburger et.al., 2007). Pernyataan dari Brown (2003) semakin 
memperkuat pendapat bahwa stimulasi diperlukan dalam perkembangan otak karena dapat meningkatkan neurogenesis dan meningkatkan kerja hipokampus sehingga dapat meningkatkan kemampuan memori jangka pendek.

Pada sampel kelompok kontrol kemampuan memori jangka pendek kategori baik menjadi minoritas dikarenakan pada kelompok kontrol tidak mendapatkan stimulasi senam otak, hal tersebut sesuai dengan pendapat Dennison (2003) yang menyatakan bahwa senam otak dapat meningkatkan kerja hipokampus dalam memori jangka pendek. Adanya responden yang memiliki kemampuan memori jangka pendek dengan kategori baik meskipun tidak mendapatkan senam otak disebabkan karena tingginya tingkat pendidikan orang tua sehingga dapat mempengaruhi pengetahuan dan sikap orang tua untuk anaknya. Hal tersebut sesuai dengan Notoatmodjo (2007) yang menyatakan bahwa semakin tinggi pendidikan seseorang, maka semakin mudah menerima informasi sehingga sèmakin banyak péngetahuan yang dimiliki yang nantinya dapat berpengaruh pada pembentukan perilaku seseofang

Kemampuan memori jangka pendek/pada kelompok eksperimen mayoritas responden memiliki kemampuan memori jangka pendek dengan kategori baik. Peningkatan kemampuan memori jangka pendek pada kelompok eksperimen sesuai dengan pendapat Greenough (2006) yang menyatakan bahwa saat ada stimulasi pada otak, misalnya senam otak maka struktur otak akan berubah dramatis, hubungan antar neuron lebih banyak, kapiler darah yang menyuplai darah dan oksigen ke otak menjadi semakin padat, sehingga dapat memperbaiki fungsi memori. Brown (2003) juga menyatakan bahwa stimulasi otak dapat meningkatkan kinerja hipokampus sehingga dapat meningkatkan kemampuan memori jangka pendek.Senam otak dapat menyatukan daerah motorik dan kognitif pada otak yang dapat meningkatkan produksi neurotropin yang dapat menambah jumlah koneksi pada syaraf otak (Blaydes, 2001).

Senam otak adalah serangkaian latihan gerakan sederhana untuk memudahkan kegiatan belajar dan penyesuaian dengan tuntutan dengan sehari-hari (As'adi, 2013). Senam otak yang dilakukan pada penelitian saat ini adalah sebanyak 24 gerakan yang terdiri dari tiga indikator yaitu dimensi lateralis (dimensi komunikasi), dimensi pemfokusan, dan dimensi pemusatan.Senam otak dapat bermanfaat untuk meningkatkan konsentrasi, mengurangi stres, meningkatkan semangat atau motivasi, meningkatkan 
kemampuan berbahasa, meningkatkan kemampuan daya ingat, meningkatkan fokus dan perhatian terhadap sesuatu (Kartini, 2007).

Data sampel pada kelompok eksperimen mengalami peningkatan pada kemampuan memori jangka pendek yaitu mayoritas memiliki kemampuan memori jangka pendek dalam rentang baik setelah diberikan senam otak selama 10 kali. Hasil yang diperoleh setelah intervensi tersebut menunjukkan bahwa latihan senam otak mampu menstimulasi hipokampus sehingga dapat mempengaruhi kemampuan memori jangka pendek pada mahasiswa IKOR FIK Unimed.

Kemampuan memori jangka pendek adalah suatu kemampuan seseorang mengingat informasi selama 30 detik (Wade, dan Tavris, 2007). Saat post test dilakukan, responden yang berada dalam kelompok eksperimen lebih cepat dan lancar dalam mengingat dan mengucapkan kembali digit-digit yang diberikan. Pengaruh kemampuan memori jangka pendek sebelum dan setelah intervensi senam otak dapat diketahui dengan melihat perubahan dari jumłah kâtâ yang dapat diingât yang mengacu pada kembar observasi IST

Penelitian ini memiliki keterbatasan diantaranya adalah :

a. Sampel kurang konsentrasi ketika dilakukan senam otak karena ada beberapa sampel yang saling menganggu.

b. Waktu penelitian tidak sesuai dengan jadwal yang ditetapkan sebelumnya karena harus menyesuaikan dengan waktu kegiatan perkuliahan.

\section{KESIMPULAN}

Berdasarkan hasil penelitian maka dapat disimpulkan sebagai berikut ada pengaruh pemberian senam otak terhadap kemampuan memori jangka pendek pada mahasiswa IKOR FIK UNIMED dengan nilai $\mathrm{p}<\alpha\left(\mathrm{p}_{\mathrm{value}}=0,004\right)$.

\section{DAFTAR PUSTAKA}

Arikunto, Suharsimi. (2006). Metodologi Penelitian. Yogyakarta: BinaAksara Bhinnety Magda. Struktur dan Proses Memori. Fakultas Psikologi Universitas Gadjah Mada. Buletin PsikologiVol 16, No.2 74-88.

Dennison, Paul. E. (2008). Brain Gym dan Aku; Merasakan Kembali Kenikmatan Belajar. Jakarta: Grasindo

Dennison, Paul. (2004). Buku Panduan Lengkap Brain Gym. Jakarta :Grasindo

Desmita.(2005). Psikologi Perkembangan.Bandung : PT. RemajaRosdakarya

Indigenous.(2010) Jurnal Ilmiah Berkala Psikologi.Vol. 12, No.1 88-99 
Insan. (2006). Prinsip-prinsip Kognitif Pembelajaran Multimedia: Peran Modality dan Contiguity. Vol 8, No. 3.

Kusumoputro, S. Lily D.S, Samino, Ruswaldi, M. \&Wahyudi, N (2003). KiatPanjangUmurDenganGerakandanLatihOtak.Jakarta : UI Press

Markam, S. Mayza, A. Pujiastuti, H. Erdat, M. S. Suwardhana. Solichien, A. (2005). LatihanVitalitasOtak. Jakarta :Grasindo

As'adi Muhammad. (2013). Tutorial Senam Otak Untuk Umum.Yogyakarta : Flash Books.

Paramitasari, D. Retno. (2011). Cara Instan Melatih Daya Ingat. Jakarta : Agogos Publishing.

Puji Leksono. (2009). “Pengaruh Senam Otak Terhadap Fungsi Memori Jangka Pendek Anak Dari Keluarga Status Ekonomi Rendah.” Program Pascasarjana Megister Ilmu Biomedik. Universitas Diponegoro Semarang.

Saputra Rengga. (2014). "Pengaruh Senam Otak Terhadap Tingkat Efikasi Diri Pada Pegawai Dinas Pemuda Dan Olahraga Kabupaten Langkat. 'Program Ilmu Keolahragaan Universitas Negeri Medan.

Sudjana.(2002). Metode Statistika.Bandung :Tarsino.

Sugiyono. (2007). Statistika Untuk Penelitian. Bandung:|CV.Alfabeta

Tim Penyusun, Pedoman Penulisan Skripsi, Járusan flmu Keolahragaan Universitas Negeri Medan 2011

Yanuarita, Andri. (2012). Memaksimalkan Otak Melalui Senam Otak (Brain

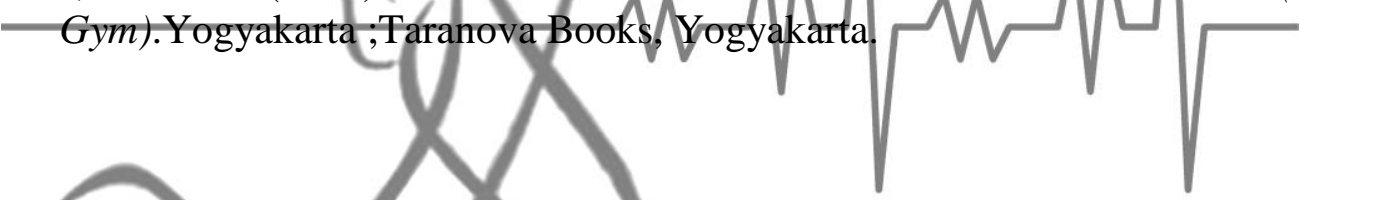

